Dr JANA ŠKERLOVÁ

Institute of History

Academy of Sciences of The Czech Republic

UDK 327(497.1:437)"1929"

Brno, Veveri 97

323(497.1)"1929"

hrabcova@brno.avcr.cz

originalan naučni rad

primljeno: 15. jun 2015.

prihvaćeno: 16. novembar 2015.

\title{
CZECHOSLOVAK-YUGOSLAV RELATIONS IN THE FIRST YEAR OF KING ALEXANDER'S DICTATORSHIP
}

ABSTRACT: This study examines bilateral political and diplomatic relations between Czechoslovakia and Kingdom of Serbs, Croats and Slovenes (from October 1929 Yugoslavia) during the year 1929 when the royal dictatorship in Yugoslavia was proclaimed. The author also focuses on the Czechoslovak attitude toward the Yugoslav dictatorship during its first year. The study is based on archival sources from the Czech and Yugoslav archives (especially diplomatic reports and correspondence) as well as literature and the press from 1929. Despite the fact that the democracy in the Kingdom of SCS was obviously curbed, Czechoslovak political leaders headed by the Minister of Foreign Affairs Edvard Beneš supported Royal Dictatorship in the Kingdom of SCS. In particular, Beneš wanted to prevent weakening of the Little Entente and also Czechoslovakia's position as its leader. This stance helped the regime in Yugoslavia to strengthen and to establish on internal and international political scene.

KEYWORDS: Czechoslovakia, Kingdom of Serbs, Croats and Slovenes, royal dictatorship, political relations, diplomacy, Little Entente

The purposes of this study are to map out Czechoslovak-Yugoslav political relations in 1929, when a royal dictatorship was proclaimed in the Kingdom of Serbs, Croats, and Slovenes (henceforth, the Kingdom of SHS), and to describe the reactions in Czechoslovakian political circles and its general public to this event. The text is based upon extensive analysis of historical sources of both Czechoslovak and Yugoslav provenience. In the course of my research, I have made particular use of documents stored in the Archives of the Ministry of Foreign Affairs in Prague (henceforth, only AMZV), especially from the Political Reports fund, which contains reports 
from the embassy in Belgrade as well as some from Czechoslovak consulates in other places, especially Zagreb. These reports are a very valuable and, indeed, irreplaceable source of information not only about Yugoslavia's relations with the Czechoslovak Republic, but also about the domestic political and foreign policy developments within Yugoslavia in the interwar period in general. Other relevant sources include the funds of Telegrams Received and Telegrams Sent, the Krofta Archives, and the Presidium of the Cabinet Council. Supplementary materials were used from the Archive of the T. G. Masaryk Institute (henceforth, only Archive of the TGM Institute), the Edvard Beneš fund, and the Archives of the President of the Czech Republic (henceforth, Archive KPR), within the fund of the Office of the President of the Republic.

Research was also undertaken in the Archives of Yugoslavia in Belgrade. Unfortunately, many of the sources relating to the history of Czechoslovak-Yugoslav relations in the interwar period have not been preserved. A great deal of interesting information, however, can still be found in the fund of the Centralni presbiro (Central Press Office), in which reports from the press attaché in Prague are held. To date, these materials in the Czech Republic have not yet been used for a study of interwar relations between the Czechoslovak Republic and Yugoslavia.

The scholarly literature contains several shorter studies that partially deal with the present subject, including some older works by Todor Stojkov and Veselin Starčević. Among the more significant recent works, we must not neglect to mention a short study by Tomáš Chrobák. ${ }^{1}$ However, none of these studies made use of materials of Yugoslav provenience, and their analysis of Czechoslovak archival material is inadequate because materials held by the KPR Archive and the Archive of the TGM institute were entirely neglected. The older works additionally suffer from the ideological encumbrances of the communist period.

During the 1920s the political situation in the Kingdom of SHS continually deteriorated, above all due to escalating ethnic conflicts. Governments frequently alternated (during the ten years of the existence of the Kingdom of SHS some twenty governments changed) and the skupština

1 Todor Stojkov, „O nastojanju jugoslavenskih vladajućih krugova da obezbede režimu monarhodiktature podršku čehoslovačke vlade (1929-1931)“, in: Jozef Hrozienčík (red.), Československo and Juhoslávia. Z dejín československo-juhoslovanských vzt'ahov, (Bratislava 1968), 269-284; Veselin Starčević, "Ohlas nastolení diktatury krále Alexandra v Československu", Slovanský přehled 65, (1979), 483-491; Tomáš Chrobák, "Diktatura krále Alexandra a československá diplomacie (1929-1931)", Slovanský přehled 94, (2008), 81-91. 
(Yugoslav Parliament) was often unable to take any action at all. The situation went so far that in June 1928 in the Parliament firearms were even used against a political opponent in an event which resulted in three deaths. ${ }^{2}$ The political crisis continued to escalate, and even the government led by the experienced Slovene politician Anton Korošec was unable to get it under control.

King Alexander Karađorđević therefore at the beginning of 1929 acceded to a radical solution. After consultations with France, he promulgated a manifesto on 6 January 1929 with which he dissolved the parliament and annulled the so-called Vidovdan Constitution from 1921. Activities of political parties were forbidden, and freedom of the press was curtailed. The government was thereupon to be answerable directly to the king. No intermediary (that is, parliament) was to stand between the king and the nation. Political parties were blamed for being the main cause of the crisis. The monarch justified proclamation of what in effect was a dictatorship as an effort to end the protracted political crisis in the Kingdom of SHS and he presented himself as the protector of national interests and the rescuer of state unity.

Alexander's decisive manner of resolving the internal political crisis was not too great a surprise to those who were politically well connected. The above-mentioned Jan Šeba, ${ }^{3}$ the Czechoslovak ambassador in Belgrade, mentioned in his report that the king had already been considering such move in the spring of 1928, but allegedly at that time had been dissuaded from this plan by the then-serving Prime Minister Velimir Vukičević, and the leader of the Slovenian clericals, Anton Korošec. ${ }^{4}$ According to Šeba's information, the king decided to solve the problem by proclaiming a military government already on 3 January. On 5 January in the evening the government was named with Petar (Pera) Živković as its leader, ${ }^{5}$ and the very same evening they also took their oaths.

${ }^{2}$ Puniša Račić, a Serbian representative of the People's Radical Party, shot several times at representatives from the Croatian Peasant Party following an inflamed debate. Pavle Radić and Đuro Basariček died on spot and Stjepan Radić died several weeks later as a result of wounds incurred during this incident. Representatives Ivan Pernar and Ivan Granđa were also wounded. Puniša Račić was condemned to twenty years imprisonment. For more information see Zvonimir Kulundžić, Atentat na Stjepana Radića (Zagreb: Stvarnost, 1967).

3 Jan Šeba (1886-1953) - Czechoslovak diplomat and politician, was the Czechoslovak ambassador to the Kingdom of SHS in 1923-1929, and in Romania in 1932-1937.

${ }^{4}$ Archiv Ministerstva Zahraničních věcí (AMZV) Prague, Political Reports (henceforth PR) - Belgrade 1929, PZ No. 3, 8. 1. 1929, pp. 1-2.

${ }^{5}$ Petar (Pera) Živković (1879-1947) - Serbian general and politician. In 1903 he took part in a coup d'état during which King Alexander Obrenović and his wife Draga were 
The manner in which the protracted political crisis in the Kingdom of SHS was resolved with the proclamation of a royal dictatorship still somewhat surprised Czechoslovak political circles, although the Czechoslovak embassy in Belgrade was already apprising of the possibility of a dictatorship arising at the end of 1928. Nevertheless, at the beginning of January 1929 they did not know what position to adopt toward the new nondemocratic regime that had taken hold in one of their closest allied states. They hesitated over whether they should, as advocates of democracy and the parliamentary system, denounce the king's radical step and risk the impairment of important relations with their ally. Or, on the other hand, out of regard for an ally that was exceptionally sensitive to any kind of criticism, to adopt a neutral position or even attempt to explain the events in the Kingdom of SHS in some way and present what had happened as the only possible and necessary solution to the difficult internal political situation in the Kingdom of SHS. ${ }^{6}$ There was also a question of what position the new government in Belgrade would take towards its Czechoslovak ally. In the telegram from 6 January in which he announced to Prague the proclamation of a dictatorship in the Kingdom of SHS, Ambassador Šeba reassured the recipients that "there is no need to fear changes toward ourselves, perhaps only from the Croat Franges ${ }^{7}$ who attacked us for agrarian tariffs ${ }^{8}$ may be unfavorable to us." However, Šeba's early information, even though he was an experienced diplomat and a man who knew the environment in Belgrade well, were not entirely accurate. He initially informed Prague that the government had been created by General Stevan Hadžić with General Danilo Kalafatović as the Minister of Foreign Affairs. This was soon proven to be only a rumor that had been spreading around Belgrade on the evening of 5 January. At the same time, he mentioned that after taking the oath he spoke with most of the ministers, which could hardly have been the truth since the government had still not yet been named. ${ }^{9}$ Thanks to the inaccurate information provided by Šeba and a subsequent malfunction of the encryption device, people in the Czechoslovak government found out about the proclamation of the dictatorship and the true situation in the Kingdom of SHS with a delay, evidently from the report from the Yugoslav press office Avala. ${ }^{10}$

killed, and the Karađorđević dynasty ascended to the throne. Later he became a member of the White Hand organization and a confidant of the prince regent Alexander.

${ }^{6}$ See V. Starčević, Ohlas nastolení diktatury, 483.

7 Oton Frangeš (1870-1945) - Croatian agronomist and politician who held the post of Minister of Agriculture in Petar Živković's government.

${ }^{8}$ AMZV Praha, Telegrams Received (henceforth, TR) 1929, No. 9/29.

${ }^{9}$ Ibid.

${ }^{10}$ AMZV Praha, PR - Belgrade 1929, secret message sent by Ambassador Šeba, 5. 3. 1929. 
Whereas Ambassador Šeba adopted an open position towards the Yugoslav regime right from the outset and enjoyed good relations with many of its representatives whom he know personally, the other important representative of Czechoslovakia in the Kingdom of SHS, the consul in $\mathrm{Za}$ greb, Jindřich Andriál, ${ }^{11}$ did not hide his marked skepticism towards the new regime and the makeup of its government. In his report from the beginning of February 1929 he did not restrain from criticism towards some of the members. He also assumed that the king had deliberately made up his government from very dissimilar personalities who often held entirely opposite political opinions so that the conflicts between then would weaken the government while at the same time enabling him to ensure that his own influence would be as great as possible. ${ }^{12}$

All the same, the CSR's position toward the new establishment in the Kingdom of SHS did not depend on either Šeba or Andriál. The main author and most important public figure of Czechoslovak foreign policy was the Minister of Foreign Affairs Edvard Beneš, and therefore the official reaction of the CSR to the proclamation of Alexander's dictatorship was derived primarily from his opinions - and Beneš was, as always, very cautious and restrained.

On 11 January; that is, five days after the proclamation of the dictatorship, Beneš sent a circular telegram out to the Czechoslovak embassies in Europe in which he summarized the Černín Palace's position on the dictatorship in the Kingdom of SHS. He explained the king's actions as something that was done when there was no other option. The king, as the last remaining authority in the country, had to intervene in a complicated political situation. Nevertheless, Beneš understood this new regime as a provisional solution that, after several months when the situation had settled down, would ultimately be replaced when the king presented the country with a new octroyed constitution. He substantiated this conjecture by pointing out the participation of three supporters of parliamentarism in the government: Vojislav Marinković, ${ }^{13}$ Nikola Uzunović, ${ }^{14}$ and Anton

${ }^{11}$ Jindřich Andriál (1888-1959) - Czechoslovak lawyer and diplomat. He served as a consul in Sarajevo (1920-1922), Split (1922-1928) and Zagreb (1928-1929) and from there he was transferred to Frankfurt am Main (1929-1936).

${ }^{12}$ AMZV Praha, PR - Zagreb consulate 1929, Special political memorandum on the new regime in the Kingdom of SHS, 8. 2. 1929.

${ }^{13}$ Vojislav Marinković (1876-1935) - Serbian politician and diplomat. Before the abolition of the political parties he had been a member of the Democratic Party. He served several times as the minister of foreign affairs, and in 1932 also briefly as the Prime Minister of the Kingdom of Yugoslavia.

${ }^{14}$ Nikola Uzunović (1873-1954) - Serbian lawyer and politician. Before the abolition of political parties he had been a member of the People's Radical Party. In the years 1926-1927 and in 1934 he was Prime Minister of the Kingdom of SHS, or Yugoslavia. 
Korošec. ${ }^{15}$ Beneš wanted to present the new Yugoslav regime at home and abroad in the best light, and by means of the Czechoslovak diplomatic representation help to build a positive image of the Kingdom of SHS in other countries as well. At the same time, of course, he did express certain misgivings about how long it would take for regime to transition from a dictatorship to another system. ${ }^{16}$ Some of the other reasons Beneš refrained from any kind of criticism of the new regime in SHS were economic. Czechoslovakia had several important open orders at the beginning of 1929 with the Kingdom of SHS; among others, large deliveries were pending for the railroad, post offices, and telegraph system, which the new government was to make decisions upon. Certainly, if only for this reason, it would have been inadvisable to subject their client to criticism that could jeopardize Czechoslovak enterprises. ${ }^{17}$ Thus, it is also thanks to the tolerant Czechoslovak attitude that these negotiations were able to proceed. ${ }^{18}$

Beneš was also concerned that any kind of further instability in Belgrade could possibly threaten the entire Little Entente, which was the alliance between Czechoslovakia, the Kingdom of SHS, and Romania, or tarnish its reputation. He therefore refused to convene the Little Entente's traditional meeting, which was to be held in the Kingdom of SHS, earlier than in May, as had been officially planned. The Yugoslav side as well as the Romanians, however, recommended convening the meeting as early as the end of February or beginning of March in order to emphasize that despite the domestic political changes in the Kingdom of SHS the Little Entente was still unified. ${ }^{19}$ Beneš refused, with the explanation that especially now, after the change of regime in the Kingdom of SHS, it would not be good to change the accustomed arrangements so that the international community would not pose needless questions on why the meeting was convened so hastily and what it might mean. Rather, he proposed to enhance the importance of the conference with the signature of mutual arbitration agreements, which would have been for both the foreign and domestic public opinion a sign of the firmness of the commitments among the states of the Little Entente. At the same time, the previously enacted treaties of alliance were to have been extended. ${ }^{20}$

${ }^{15}$ Anton Korošec (1872-1940) - Slovenian Catholic priest and politician, leader of the Slovene People's Party. In the years 1928-1929 he was the Prime Minister of the Kingdom of SHS, and after the coup d'état he defected to the opposition.

${ }^{16}$ AMZV Praha, Telegrams Sent (henceforth, TS) 1929, No. 21-39/29.

${ }^{17}$ Ibid., PR - Belgrade 1929, PR No. 3, 8. 1. 1929, p. 9.

${ }^{18}$ Ibid., PR - Belgrade 1929, Delivery of Railway Material to SHS, 14. 3. 1929.

${ }^{19}$ Ibid., TR, No. 61/29, 24. 1. 1929; No. 65/29, 25. 1. 1929; No. 70/29, 26. 1. 1929;

No. 72/29, 27. 1. 1929; No. 80/29, 29. 1. 1929.

${ }^{20}$ Ibid., TS, 252-253/29, 2. 4. 1929; No. 322/29, 15. 5. 1929. 
King Alexander appreciated Beneš's position, as he repeatedly communicated in a private interview with Šeba, first in January immediately after his takeover, and then again with somewhat more reserve in March. ${ }^{21}$ The Yugoslav monarch was also satisfied with the manner in which Beneš provided information to the Czechoslovak press about the coup d'état. On 10 January, Šeba reported to Prague that King Alexander "[sends] many thanks for understanding the situation in SHS, and that he greatly esteems the breadth of Minister Beneš perspective, and that he is pleased to once again be assured of what kind of friend SHS has in Min [ister] Beneš, which is recognized in difficult moments." 22 Šeba also in his private correspondence confirmed Beneš' theory about the temporariness of the regime in the Kingdom of SHS, as he expressed the opinion that it was expected that in the fall of 1929 in the Kingdom of SHS there would be discussion of elections, for a very banal reason. The Kingdom of SHS found itself in a distressing economic situation and it would have been very difficult for the dictatorship to obtain a foreign loan. ${ }^{23}$ The new government had to resolve not only its prewar debts to France, but also the debts of the previous government, which in the hopes of obtaining a foreign loan had embarked upon extensive investment programs, such as, for example, the construction of a second railway track for the route between Zagreb and Belgrade. ${ }^{24}$ The military attaché in Belgrade, Lieutenant Colonel Rudolf Vyčítal, therefore suggested to Beneš that Czechoslovakia provide the Kingdom of SHS with a loan, and thus strengthen not only their mutual alliance, but also Czechoslovakia's prestige within SHS. ${ }^{25}$

Beneš' positions and the way he used his influence to create a positive image for the Kingdom of SHS after the proclamation of a dictatorship was also appreciated by the new Prime Minister Petar Živković, who, afterward, gave his thanks to Ambassador Šeba in Prague at the end of January. ${ }^{26}$ It is said that he proclaimed that he "thanks Minister Dr. Beneš for the real, allied assistance he provided in our own and in the foreign press", as Šeba telegraphed to Prague. ${ }^{27}$ Živković also attempted to reassure Pra-

${ }^{21}$ Ibid., TR, Copy, No. 22/29, 10. 1. 1929; Archive of the T. G. Masaryk Institute in Prague (AÚTGM Praha), f. Edvard Beneš I (henceforth, EB I), k. 170, sign. R 309/2a, Letter by J. Šeba from 9. 3. 1929, f. 11.

${ }^{22}$ AMZV Praha, TR 1929, No. 22/29.

${ }^{23}$ AÚTGM Prague, f. EB I, k. 170, sign. R 309/2a, letter by J. Šeba from 7. 4. 1929, f. 112 .

${ }^{24}$ AMZV Praha, PR - Belgrade 1929, PZ No. 14, 6. 3. 1929, p. 6.

${ }^{25}$ AÚTGM Praha, f. EB I, k. 170, sign. R 309/2a, Report by military attaché Lt. Col. Rudolf Vyčítal from 9. 6. 1929, Aide memoire, pp. 3-4.

${ }^{26}$ AMZV Praha, PR - Belgrade 1929, PZ No. 5, 21. 1. 1929, p. 1; Ibid., TD 1929, No. $31 / 29$.

${ }^{27}$ Ibid., TR 1929, No. 31/29. 
gue that in Czechoslovak-Yugoslav relations absolutely nothing had changed. On the contrary, he expressed the hope that they would be closer than ever. At the same time, Živković was very concerned to assure Šeba that the new regime was not the kind of military dictatorship it might look like at first glance because the Prime Minister was closely connected with the army. Even this assurance about the character of the regime bore witness that Belgrade was making efforts to be perceived in the best light possible abroad.

Minister of Justice Milan Srškić also expressed similar ideas about Czechoslovak assistance in an interview with the ambassador. At the same time he emphatically appealed to Šeba to let them know in Prague that the new regime truly had only a provisional character and as soon as its tasks were accomplished there would be a return to the parliamentary system. He himself estimated that the interim period would last about a year. ${ }^{28}$

Another piece of evidence for King Alexander's good relations with Czechoslovakia is provided by his visit to the new building of the CSR's Belgrade embassy on 23 February $1929 .{ }^{29}$ This visit was of a purely private nature: the king was interested in having a look into the new premises of the embassy and according to his host, Ambassador Šeba, neither domestic nor foreign politics were spoken of. This was surely deliberate on the king's side. Nonetheless, this visit excited significant public interest in Belgrade, because it was the first visit that the king paid to any legation after his seizure of power. The court even had to downplay the official significance of the visit so that the other embassies did not feel slighted that the Yugoslav ruler had not visited them as well. ${ }^{30}$ The visit testifies that the king's relationship with Czechoslovakia was very good after the proclamation of his dictatorship. If he had been dissatisfied with the Czechoslovaks he certainly would not have paid what was essentially a friendly visit to an ambassador, dining and playing cards.

In May 1929 the regular conference of the Little Entente took place in Belgrade and the Czechoslovak minster of foreign affairs could see with his own eyes how the new system in the Kingdom of SHS was working. After his return home, Beneš sent out a circular telegram to the Czechoslovak diplomatic offices in which he summarized his impressions from his visit to the Kingdom of SHS. Beneš wrote about the great authority of the king, and that the king and the army have the situation under control and that in the Kingdom of SHS there was no mass opposition movement. Nor did

${ }^{28}$ Ibid., PR - Belgrade 1929, PZ No. 5, 21. 1. 1929, pp. 4-6.

${ }^{29}$ Ibid., TR, No. 176/ 29, 1. 3. 1929.

30 Ibid., PR - Belgrade 1929, King Alexander's Visit to the Czechoslovak Embassy 9. 3. 1929 , pp. $6-7$. 
Beneš consider the king's initiative of abolishing political parties as being of much importance: "There have been and will be great difficulties, but the Radical Party and the most of the Democratic Party do not have anything at all against the king and will not strike against the regime." ${ }^{31}$ Beneš, of course, did not disguise his feelings that if the dictatorship were to last too long nothing good would come of it. According to his messages, however, a new constitution was already being drafted in May and there was work being done on unifying the country's legislation. Beneš mentioned that the financial difficulties in the Kingdom of SHS also were not as serious as foreign propaganda had described. He further instructed Czechoslovak diplomats not to share this classified information they had received from him anywhere else, but they were to "use it discreetly in order to everywhere scaremongering news is being spread that would damage SHS and the Little Entente. Our policy must now be to help SHS everywhere so that the Yugoslavs can come out of this, strengthened, as quickly as possible." 32 In a similar vein, Beneš' deputy Kamil Krofta also transmitted his boss' opinion at the meetings for section leaders in the Ministry of Foreign Affairs when he stated that Beneš came back from Belgrade satisfied and returned with a good impression, especially of the king who, in his opinion, should be considered the most competent man among the Yugoslav politicians. According to Beneš, the king girded up his courage to execute the coup perforce in order to put an end to corruption. ${ }^{33}$ Regarding the matter of the constitution, certainly Beneš showed himself to be too much of an optimist. In the fall of 1929 a constitution was still not in sight, although it was rumored that one might appear in January 1930, on the first anniversary of the proclamation of the dictatorship. ${ }^{34}$ Finally, King Alexander issued a new constitution by decree on 3 September 1931.

Officially, even after the proclamation of Alexander's dictatorship, Czechoslovakia and the Kingdom of SHS were still the closest of allies. This is how the mutual relations were presented by both countries' official political representations to their publics as well as abroad. Even though the official Czechoslovak policy was to unconditionally support its ally, some opponents and critics of the new Yugoslav establishment could be found in the CSR. They were troubled by its undemocratic character, the suppression of the rights of the non-Serbian nations, persecution of the opposition, and the curtailment of civil rights. At the same time, they were also vexed

${ }^{31}$ Ibid., TS 1929, No. $474-493 / 29$.

${ }^{32}$ Ibid.

${ }^{33}$ AMZV Praha, f. Krofta Archive (hereinafter, KA), k. 8, commentary by Minister Dr. Krofta, submitted on 6 June 1929 to the leaders of sections and divisions, p. 1.

${ }^{34}$ AMZV Praha, PR - Belgrade 1929, PZ No. 68, 8. 12. 1929, p. 5. 
by the hypocrisy of Czechoslovak foreign policy, which overlooked all of these sins in the interest of preserving the stability of the Little Entente and its external image. Furthermore, they were disenchanted with the way that, starting in 1930, the Czechoslovak press became a mouthpiece for these policies. Unlike the Kingdom of SHS the press in Czechoslovakia was not significantly restricted or censored, even though according to the 1923 Law for the Protection of the Republic, newspapers could be suspended in the case of so-called illicit reporting, a category that included, for example, coverage giving sanction to criminal acts or encouraging people not to fulfill their legal duties. Despite this, the Czechoslovak press was able to freely express opinions about the situation in the Kingdom of SHS (which was renamed the Kingdom of Yugoslavia in October 1929), a freedom which during the period of 1929-1934 often aroused a great deal of disapproval of the politicians there. They often did not hesitate to intervene with the Czechoslovak embassy in Belgrade or, through their press attaché, intercede directly at the Ministry of Foreign Affairs in Prague. Immediately after the proclamation of the royal dictatorship, however, the situation was different. The Ministry of Foreign Affairs avoided any kind of critical reactions and attempted to impress a similar mindset upon the Czechoslovak press, especially the left-center papers that were well disposed toward the Castle. Even other newspapers, with the exception of the communist press, ${ }^{35}$ without regard for their political orientations, did not much criticize the proclamation of the dictatorship.

Overall, the Czechoslovak press had a rather restrained reaction to the proclamation of the dictatorship itself. Journalists usually avoided using the word dictatorship in connection with the new Yugoslav regime and for the most part refrained from any kind of commentary and merely provided information about the events without attempting to evaluate them. With only a few exceptions, the proclamation of the dictatorship was interpreted as an entirely positive event in the Czechoslovak press. Although a few commentators carefully admitted that there was limitation of democracy, they immediately added that all the measures taken were only temporary and they were unavoidably necessary to resolve the state crisis. For example, well-known correspondent Hubert Ripka ${ }^{36}$ in the leading article for the bi-weekly Národní osvobození on 9 January delivered the admonition: "It is not a defeat of democracy, though certainly a warning for all democratically-oriented societies." ${ }^{37}$ Czechoslovak newspapers also gave

${ }^{35}$ For example, see Rudý večerník, 7. 1. 1929.

36 Hubert Ripka (1895-1958) - Czech correspondent and politician. He first worked for Národní osvobození, then after 1930 for Lidové noviny.

${ }^{37}$ Národní osvobození, 9. 1. 1929. 
space to the Yugoslav opposition, which took shape immediately after the proclamation of the dictatorship. The movement's center became the Croatian city of Zagreb. ${ }^{38}$ Only four days after the coup there were already appearing reports about a bleak mood in Croatia, of the dissolution of political parties, restrictions on freedom of the press, abolishment of the independent judiciary and further restrictions as well as the restrained reactions of the foreign press. ${ }^{39}$ These alternated with positive receptions borrowed from the Zagreb newspapers, but the original enthusiasm and optimism were gone. ${ }^{40}$ Several days later Vladimir Maček, ${ }^{41}$ the leader of the Croatian Peasant Party (which became illegal in January 1929), summarized Croatians' demands in an interview with a Hungarian reporter that was also reprinted by Lidové noviny under the title of Croatian Reproaches to the New Regime: "We Croats with to have an independent legislature within the framework of the state and executive power in all domestic affairs. In relations with other countries we want a unified state with the Serbs; however within the framework of this Yugoslav state we wish for the renewal of the sabor [Croatian Parliament] and a Croatian government accountable to that assembly." ${ }^{42}$ That the Czech newspapers publicized the standpoint of the Croatian opposition does not mean even by a long shot that they agreed with this standpoint or supported it. Rather, there were commentaries critical to the opposition. ${ }^{43}$ The idea of one Yugoslav nation continued to be generally accepted in the ČSR and very few were willing to admit that the conjoining of three brotherly south Slavic nations would not necessarily meet with success, through the greater or lesser fault of any of them.

In March 1929 a commentary published in Národni listy pointedly summarized the circumspect approach of the Czech press and the public response to it in the Kingdom of SHS: "In Belgrade, in Zagreb, in Ljubljana they would wish for the Czech press would adopt a standpoint that was forthright and clear toward the new regime, and the Czech position of only reporting and informing about the events in Yugoslavia without observing them critically or expressing opinions seems incomprehensible. Some politicians do not want to understand that there is, in fact, no other way, if there is a desire not to do damage or erect obstacles to an enterprise that

${ }^{38}$ On the question of the opposition in Yugoslavia, see Todor Stojkov, Opozicija $u$ vreme šestojanuarske diktature 1929-1935 (Beograd: Prosveta, 1969).

${ }^{39}$ Národní listy, 10. 1., 11. 1. 1921; Národní osvobození 10. 1. 1929.

${ }^{40}$ Národní listy, 12. 1. 1929.

${ }^{41}$ Vladimir (Vladko) Maček (1879-1964) - Croatian politician, who after the death of Stjepan Radić served as leader of the Croatian Peasant Party.

${ }^{42}$ Lidové noviny, 16. 1. 1929.

${ }^{43}$ See, for example: Rudolf Procházka, "Jak jest demokracie možná?", Přitomnost 6 , (1929), 49-50. 
was certainly meant well, than to refrain from meddling in the internal affairs of another state, not to stand in its way, but rather to support its every effort for a better future. This is our most reliable ally and any ever so well-meant action at all could be taken advantage of by enemies, of which there are more than enough waiting for the chance." ${ }^{44}$ In a similar gist, one of the leading representatives of the opposition, Većeslav Vilder, ${ }^{45}$ also complained about the style of writing in the Czechoslovak press in his letter to the chancellor of President Masaryk, Přemysl Šámal. ${ }^{46}$ Vilder wrote that to a significant extent the circumspect position of a Czechoslovak official policy that does not want to meddle in the domestic affairs of an allied country is understood in Croatia, but at the same time adding that they regret that in Czechoslovakia "there cannot be found even one independent paper that would at least regard our current regime with any skepticism." ${ }^{47}$

Despite that the official policy and the Czechoslovak press had adopted a positive or at least a reserved position on the proclamation of the dictatorship in the Kingdom of SHS, in the anniversary report for 1930 sent to Belgrade in January 1931, the Yugoslav press attaché evaluated the Czechoslovaks' position towards the dictatorship after its proclamation as generally rather skeptical and none too enthusiastic for a government without a parliament. The Yugoslavs admitted that the pro-government Czechoslovak press attempted to clarify the reasons that led to the installation of a royal dictatorship in Yugoslavia to the general public, but the result of their efforts was not what had been expected. In particular, the Czechoslovak Catholics influenced by Rome, in their view, had adopted a negative stance toward the Yugoslav regime, as had the communists and to a significant extent, also the Social Democrats. ${ }^{48}$

Minister Beneš personally took a great deal in Czechoslovakia's effort to create the best possible image of the Kingdom of SHS abroad. Any further destabilization to the regime in the allied country could threaten the whole system it was linked up with, which above all meant a risk to the Little Entente that Beneš had been laboriously building for the whole of the 1920s and whose prestige and international significance he cared so deeply about.

\footnotetext{
${ }^{44}$ Národní listy, 17. 3. 1929.

${ }^{45}$ Većeslav Vilder (1878-1961) - Croatian journalist and politician, graduate of the law faculty in Prague, member of the Independent Democratic Party.

${ }^{46}$ AKPR, Praha, f. KPR, sign. T 1011/22, Yugoslavia I, Letter by Većeslav Vilder to Chancellor Šámal from 10. 4. 1929.

47 Ibid.

${ }^{48}$ Archive of Yugoslavia/Arhiv Jugoslavije (henceforth AJ), Beograd, f. 38, Centralni presbiro (henceforth, CP), k. 33, 80 - Čehoslovačka, Godišnji izveštaj dopisnika Centralnog presbiroa u Pragu, januar 1931.
} 
Beneš was, of course, well enough informed to know that the real situation the Kingdom of SHS was not as favorable as the impression he was trying to give outwardly. Unlike the messages from Belgrade, where Ambassador Šeba understood the new regime as a means that was necessary for the country's consolidation, other messages were coming in different parts of the country that were written in an entirely opposite spirit. In particular, they were being dispatched from the consulate in Zagreb, which had been led since 1928 by Consul Jindřich Andriál. He was sending messages that were quite critical toward the Yugoslav regime, some of its ministers, and even the king. ${ }^{49}$ The consul saw reasons for the crisis that had led up to the coup d'état on both the Serbian and the Croatian sides: "Serbia corrupted the state with its political partisanship and unqualified bureaucratism and Croatia with its political negativism and the nebulousness of its political doctrines," wrote Andriál in one of his messages to Prague. ${ }^{50}$ He saw another large problem in the centralizing constitution, which strengthened the position of the Serbs at the expense of other nations and in the approach taken by the king, who, in his opinion, always felt himself to be more of a Serb than a Yugoslav and never spent any greater length of time in Zagreb in order to make up his own opinion on the situation, and therefore who easily fell under the influence of various anti-Croat intriguers. The consul understood the current situation as a first step toward a republic. $^{51}$

Consul Andriál also drew attention to the growing radicalization of Croatian politics and society, to the increasing influence of the communists and nationalists, even though Ante Pavelić, the leader of the separatist Croatian organization Ustaša, in his opinion was only a marginal figure of the Zagreb political scene. At the same time, the Zagreb consul was disturbed by the increase in political violence that culminated with the murder of Toni Schlegl the editor of the pro-regime Zagreb press concern Yugo Stampa, with whom the Zagreb consulate as well as the Belgrade embassy had maintained certain relations. The murder of T. Schlegl, which the authorities suspected was done by radićevci ${ }^{52}$ or frankovci (Frankists), ${ }^{53}$ was evidence that the Croatian question remained alive and unresolved.

At the end of April 1929 Beneš received an unsigned letter from the Czechoslovak consulate in Zagreb, where the author, who was in all likelihood

${ }^{49}$ AMZV Praha, PZ - Belgrade 1929, special political report about the new regime in the Kingdom of SHS, 8. 2. 1929.

${ }^{50}$ Ibid., p. 10.

${ }^{51}$ Ibid., p. 11.

${ }^{52}$ Partisans of the Croatian Peasant Party and its murdered leader Stjepan Radić.

${ }^{53}$ Frankovci - originally the name of the fraction of the Croatian Party of Rights, radical nationalists who were hostile towards the Serbs. 
Consul Andriál himself, described the situation of the opposition and the mood prevalent in the society in great detail. Here are the words he wrote: "Everyone agrees - especially in Serbia - that the King is incapable, the government that he selected can manage an ordinary agenda, and the kinds of reforms for which expertise suffices. However, money is missing. A foreign loan is not forthcoming so long as those abroad are not convinced that the given consolidation is a path leading to a constitutional life." ${ }^{54}$

In a similar spirit Andriál also reported on Beneš' deputy Kamil Krofta in a personal letter. ${ }^{55}$ Andriál expressed the conviction that so long as there wasn't a change in regime, and not only the "cosmetic" improvements to the government that the king was planning, but so long as a constitution was not instituted, and elections were not held, there was the threat of an assassination of the king in Zagreb or even in Belgrade, as well as a revolution. Andriál also complained that Ambassador Šeba was supplying misinformation about the situation in Yugoslavia was and was "eating from the hand" of the regime, which was damaging the CSR in the eyes of democrats and causing a diminution of the authority of Minister Beneš as well as President Masaryk. ${ }^{56}$

The Czechoslovak minister of foreign affairs, of course, was not too well disposed toward Andriál's messages. They were also dissatisfied with his conduct and the manner in which Andriál reported on the situation at his workplace to Prague in Belgrade. At the end of June, even the minister of foreign affairs Vojislav Marinković requested via Ambassador Šeba that Andriál be withdrawn from Zagreb, which did come to pass in September 1929. His post was then taken up by Ondřej Pukl. ${ }^{57}$ At the same time, Marinković requested that Beneš not elevate the representation in Zagreb to a general consulate because in Croatian circles that could, in his opinion, give the impression of Czechoslovakian acquiescence with the Croatian demands and an indication of a change in the line of Czechoslovak policy towards the dictatorship. ${ }^{58}$ In this, too, Beneš accommodated the Yugoslav side's wishes.

Whereas there was dissatisfaction with Andriál's functioning in official circles in Belgrade, representatives of the Yugoslav opposition were

\footnotetext{
${ }^{54}$ AÚTGM Prague, f. EB I, k. 170, sign. R 309/2a, correspondence 1929 - unsigned, f. 1.

${ }_{55}$ AMZV Praha, f. KA, k. 13, Yugoslavia (Zagreb) - information about the situation in 1928-1929, letter by Zagreb consul Andriál to K. Krofta from 25. 4. 1929.

${ }^{56}$ Ibid., letter undated.

57 AMZV Praha, f. Presidium MZV, k. 162, Zagreb consulate, summary of official activities in the 2nd half of 1929.

Ondřej Pukl (1876-1936) - Czechoslovak diplomat and chemist who served as the consul in Zagreb in 1920-1922 and 1929-1934.

${ }^{58}$ AMZV Praha, TR, No. 491/29; Ibid., PR - Belgrade 1929, PR No. 36, 9. 7. 1929.
} 
disillusioned by Ambassador Šeba's positions. They reproached him for his friendship with a "reactionary clique" and admiration for absolutism. ${ }^{59}$ Šeba, however, continued to further remain faithful to the party line espoused by Minister Beneš.

While in the Kingdom of SHS, despite various minor political squabbles, the situation had already begun to slowly simmer down by the summer of 1929, in the CSR it grew more complicated. In 1929 the trial of Vojtech Tuka, the Slovak representative of Hlinka's Slovak People's Party, culminated. After Tuka was sentenced, his party left governing coalition, which led to early elections that took place in the CSR in October 1929. The Yugoslav side was attentively following the premature elections in Czechoslovakia. They were particularly concerned that Czechoslovakia's foreign policies towards Yugoslavia remain favorable. Each weakening of foreign policy support could weaken the Yugoslav regime. There was, however, a general expectation that Beneš' party and, along with it, his own position would be strengthened after the elections, so the Yugoslavs were altogether equanimous. ${ }^{60}$

The situation after the election, however, was somewhat discouraging, as the old coalition made up of the Agrarian Party, the Hlinka's Slovak People's Party and several smaller parties emerged weakened and the negotiations to build a new government lasted six weeks. In the end, it was led by the Agrarians, this time in cooperation with the Social Democrats, Czechoslovak People's Party, and several other smaller parties. Edvard Beneš kept the post of Minister of Foreign Affairs, despite others, such as the Agrarian party member and chairman of the Czechoslovak-Yugoslav League Milan Hodža, having taken a shine to it. ${ }^{61}$ And there were no significant changes registered in Czechoslovakia's foreign policy or attitudes towards the Yugoslav regime.

At the end of September 1929 Ambassador Jan Šeba vacated his long-term station in Belgrade (where he had been serving since 1923), and ran for office in the elections with the Czechoslovak National Socialist Party. Unlike consul Andriál, Šeba departed from Belgrade while still enjoying good relationships with the government and with the king, who had organized a royal hunt in his honor. ${ }^{62}$ Administration of the embassy was taken

${ }^{59}$ AKPR, Praha, f. KPR, sign. T 1011/22, Yugoslavia I, Letter from Većeslav Vilder to Chancellor Šámal from 10. 4. 1929.

${ }^{60}$ AJ, Beograd, f. 38, CPB, k. 32, 77 - Čehoslovačka, Zpráva tiskového attaché vyslanectví Království SHS in Prague, 7. 10. 1929.

${ }^{61}$ See Zdeněk Kárník, České země vére první republiky (1918-1938). Díl první. Vznik, budování a zlatá léta republiky (1918-1929), (Praha: Libri, 2000), 557.

${ }^{62}$ AMZV Praha, PR - Belgrade 1929, Telegram by Ambassador Šeba, No. 686/29, 9. 11. 1929. 
over by the chargé d'affaires Lev Vokáč ${ }^{63}$ who had been working in Belgrade since 1927, and who knew the Serbian environment very well. Vokác took over the leadership of the Belgrade mission in a complicated time. Unlike Jan Šeba, Vokáč had never been an unreserved supporter of the Yugoslav regime or towards Beneš' attitude towards it. His messages were characterized by critical stances towards the dictatorship and the general conditions obtaining in Yugoslavia.

Minister Beneš procrastinated in filling the ambassador's post in Yugoslavia. He sought a suitable candidate, because Belgrade was a key ally for him and the personality of the intermediary between the Czechoslovak and Yugoslav governments could have a crucial influence on the relations between the two states, and this important diplomatic post also carried a great deal of political weight. Representative Antonín Uhlír was one of the candidates who is often mentioned ${ }^{64}$ others who were under consideration included the career diplomat Josef Švagrovský, ${ }^{65}$ who had already worked in Belgrade as a chargé d'affaires, Robert Flieder, and Bohdan Pavlů. Information about who would become the new Czechoslovak ambassador in Belgrade was naturally also of enormous interest to the Yugoslavs, and therefore the Yugoslav embassy was regularly reporting back to Belgrade with the development of the situation and all new information. Already by the middle of October 1929 it seemed that Robert Flieder had the best chance, but the Prague embassy reported to Belgrade that he definitely didn't have the required qualities to occupy the post, and the achievements in his career so far were owed mainly to his family connections (specifically to his father-in-law František Veselý, a senator with the Czechoslovak National Democracy party). Bohdan Pavlů, who had previously served as an ambassador in Sofia, was considered to be the best candidate. ${ }^{66}$

In the face of reports about the possible normalization of relations within Yugoslavia that were rampant at the end of 1929 and the beginning of the next year, Prague continued to bide its time with the nomination of another ambassador for Belgrade. Finally, it was in June 1930 that Robert Flieder was appointed new Czechoslovak ambassador to Yugoslavia. ${ }^{67}$ The Yugoslav embassy then repeated back to Belgrade that of all the candidates,

${ }^{63}$ Lev Vokáč (1883 - ?) - Czechoslovak lawyer and diplomat who starting in 1927 worked as the legation counsellor in the in the Belgrade embassy.

${ }^{64}$ Večer, 9. 10. 1929.

${ }^{65}$ AJ, Beograd, f. 38, CPB, k. 32, 77 - Čehoslovačka, report from the press attaché of the Kingdom of SHS in Prague, 10. 10. 1929.

${ }^{66}$ Ibid., message from the press attaché of the embassy of the Kingdom of SHS in Prague, 19. 10. 1929.

${ }^{67}$ Robert Flieder (1883-1957) - Czech lawyer and diplomat. He served as an ambassador in Switzerland, Poland, Sweden, Yugoslavia and Spain. 
the one selected was the least capable and had gained his post thanks to nepotism. ${ }^{68}$

While the pre-election battles were raging in Czechoslovakia, in Yugoslavia there were significant administrative changes taking place. On 3 October 1929 a law was passed that changed the official name of the country to the Kingdom of Yugoslavia and which enacted a new administrative division of the country into nine segments (banovina), each of which was to be ruled by a ban, a provincial governor appointed by the king. According to the official explanations, this new law had the goal of reducing chauvinism - both Croatian and Serbian. In Croatia it was fairly well received. There was a rapid re-naming of all kinds of organizations and companies, where the word "Croatian" was replaced with the word "Yugoslav". ${ }^{69}$ The Croats were hoping that within the framework of their division into banates they would achieve a greater degree of local selfgovernment. ${ }^{70}$ By contrast, in the Serbian parts of the land reception of the country's new official name and its administrative divisions was somewhat more lukewarm.

Czechoslovakia acknowledged the renaming. On 4 October the Ministry of Foreign Affairs in Prague received a verbal note in which the change of name was announced, ${ }^{71}$ and responded by circulating a memorandum with instructions that henceforth only that name was to be used. ${ }^{72}$ The Czechoslovak press also reacted to the new name of their allied state, and took the change of the country's name to Yugoslavia as a positive step.

The closer the one-year anniversary of the establishment of the dictatorship approached, the more nervous the Yugoslav regime became. The government attempted to complete various tasks, especially passing new laws in order to be able to boast abroad how much work it had managed to accomplish in one year. They also planned various appreciative and eulogistic deputations, particularly of Croatian peasants, but also of urban citizens in order to show the world that the people in the Kingdom of Yugoslavia were satisfied with the new regime. The goal was especially to improve the regime's image abroad and to assist them in obtaining the foreign loans that Yugoslavia so urgently needed, but without a parliamentary regime

${ }^{68}$ AJ, Beograd, f. 38, CPB, k. 32, 77 - Čehoslovačka, message by the press attaché of the embassy of the Kingdom of Yugoslavia in Prague, No. 76/30, 2. 3. 1930.

${ }^{69}$ AMZV Praha, PR - consulate Zagreb 1929, report on the enactment of a law on 5 December 1929. Undated.

${ }^{70}$ Ibid.

${ }^{71}$ Ibid., f. Presidium MZV, k. 30, Yugoslavia, Verbal memorandum by the Embassy of the Kingdom of SHS in Prague, 4. 10. 1929.

${ }^{72}$ Ibid., f. Presidium MZV, k. 30, Yugoslavia, Change in the Official Name of SHS to the Kingdom of Yugoslavia, 24. 10. 1929. 
was hardly able to procure. Again, the introduction of an octroyed constitution was spoken of, but it still did not happen, ${ }^{73}$ and the regime still found itself unable to solve the Croatian question.

At the end of 1929 Anton Korošec, a minister and experienced politician, was sent to Austria and Germany for the purpose of improving Yugoslavia's image abroad and gaining sympathy against Italy. According to the information from chargé d'affaires Vokáč, Korošec was to make a stop in Prague on his return trip and inform Minister Beneš about the results of his mission, because "Yugoslavia, as it is said here, considers it its responsibility to enter into relations with the Czechoslovak Republic, as soon as there is any kind of more significant act taken concerning the foreign policy of Central Europe in just the same way as the Czechoslovak Republic assists Yugoslavia with its Balkan politics." ${ }^{\text {74 }}$ Korošec, however, did not make a stop in Prague, which aroused various speculations about the degree of success of his mission. ${ }^{75}$

In the beginning of December 1929 the traditional celebrations of the proclamation of the Kingdom of SHS took place; however, this was the first time it happened under the governance of the new regime. Traditionally, this commemoration was also celebrated in Prague, where a gala concert would be held in the Smetana Hall of the Municipal House, and President Masaryk was invited to the event. ${ }^{76}$ The Yugoslavs cared very deeply about having him attend the concert, because it would have been a sign that Czechoslovak-Yugoslav relations were still very good even after the regime change and that the CSR did not have any fundamental criticisms of the dictatorship. Therefore, the Yugoslav ambassador Grgur Anđelinović supported the entreaty by personally delivering the invitation to the event in the president's office. ${ }^{77}$ His office, however, excused President Masaryk on the grounds of his crushing burden of work during the period of assembling the new cabinet. ${ }^{78}$ Minister Beneš, however, thought that it would not be good to entirely rebuff the invitation, so therefore Chancellor Šámal

\footnotetext{
${ }^{73}$ AMZV Praha, PR - Belgrade 1929, PZ No. 68, 8. 12. 1929.

${ }^{74}$ Ibid., PR No. 70, 17. 12. 1929, p. 3.

${ }^{75}$ Ibid., PR No. 1, 2. 1. 1930, p. 11.
}

${ }^{76}$ Archives of the President of the Czech Republic (AKPR), Praha, f. KPR, k. 128, sign. D 11311, Yugoslavia, folder entitled National Holiday of the Kingdom of Yugoslavia 1 December, record from 29 November 1929.

${ }^{77}$ Ibid., record from 14 November 1929.

Grgur Budislav Anđelinović (1886-1946) - Croatian Dalmatian journalist, politician and diplomat. He served in the function of Yugoslavia's ambassador to Prague in 19291930.

78 AKPR, Praha, f. KPR, k. 128, sign. D 11311, Yugoslavia, letter to Chancellor Přemysl Šámal to Ambassador Anđelinović, 27. 11. 1929. 
attended the concert as in place of the president. ${ }^{79}$ Masaryk's absence, however, indicated what had only been speculated about: that Masaryk, unlike Beneš, was not so well disposed towards the new Yugoslav regime.

The Czechoslovak Ministry of Foreign Affairs had sufficient intelligence about the situation in the Kingdom of SHS in 1929, both from its own sources (the consulate in Zagreb and embassy in Belgrade), as well as directly from those involved in the events (such as Svetozar Pribićević and Većeslav Vilder), and even from outside observers (for example British journalist and historian R. W. Seton-Watson who in 1929 visited Yugoslavia and later also Czechoslovakia where he spoke to Beneš and Masaryk). Last but not least, Minister Beneš also had the opportunity to evaluate the situation for himself during the conference of Little Entente states, even though at that time he naturally only met with official representatives of the state and not with any delegates from the opposition. Beneš continued even in the future to toe the official line of absolute support for the royal dictatorship and to excuse any possible excesses of the regime as steps necessary to maintain order. Despite occasional problems, the mutual Czechoslovak-Yugoslav relations appeared in 1929 to be exemplary, as witnessed by a dispatch from the British ambassador in Belgrade, Neville Henderson. At the beginning of 1930 he wrote in a message that summarized the events of 1929 in Yugoslavia that there had not appeared any signs of weakening in the countries' mutual relations and that Czechoslovakia was following Yugoslavia's internal difficulties with sympathy and refraining from making assessments or criticism. ${ }^{80}$

In the efforts not to jeopardize or weaken the foreign political position of the Little Entente in the European political arena, Minister Edvard Beneš had opted for a supportive approach towards the Yugoslav dictatorship, despite its evident non-parliamentary and a non-democratic stance. His outwardly reserved approach and de facto silent support on behalf of a Czechoslovakian foreign policy thus enabled the Yugoslav regime to establish and consolidate itself.

${ }^{79}$ Ibid., record from 29 November 1929, comment by Chancellor Šámal.

${ }^{80}$ Annual report by Ambassador Henderson for the year 1929 from 5. 2. 1930, in: Yugoslavia. Political Diaries 1918-1965, Volume 2: 1927-1937, Robert L. Jarman (ed.), (Slough: Archive Editions, 1997), 158. 


\section{SOURCES AND LITERATURE}

Archive of Yugoslavia/Arhiv Jugoslavije (AJ), Beograd, f. 38 Centralni presbiro (CPB).

Archiv Ministerstva Zahraničních věcí (AMZV), Praha: Political Reports; Telegrams Received; Telegrams Sent; Krofta Archive; Presidium MZV.

Archives of the President of the Czech Republic (AKPR), Praha, f. KPR.

Archive of the T. G. Masaryk Institute in Prague (AÚTGM), Praha, f. Edvard Beneš I.

Yugoslavia. Political Diaries 1918-1965, Volume 2: 1927-1937. Robert L. Jarman (ed.). Slough: Archive Editions, 1997.

Lidové noviny (1929)

Národní listy (1929)

Národní osvobození (1929)

Rudý večerník (1929)

Večer (1929)

Chrobák, Tomáš. "Diktatura krále Alexandra a československá diplomacie (1929-1931)". Slovanský přehled 94, (2008), 81-91.

Kárník, Zdeněk. České země v ére první republiky (1918-1938). Díl první. Vznik, budování a zlatá léta republiky (1918-1929). Praha: Libri, 2000.

Kulundžić, Zvonimir. Atentat na Stjepana Radića. Zagreb: Stvarnost, 1967. (1929), 49-50.

Procházka, Rudolf. "Jak jest demokracie možná?". Př́tomnost 6 ,

Starčević, Veselin. "Ohlas nastolení diktatury krále Alexandra v Československu". Slovanský přehled 65, (1979), 483-491.

Stojkov, Todor. „O nastojanju jugoslovenskih vladajućih krugova da obezbede režimu monarhodiktature podršku čehoslovačke vlade (19291931)“. In: Jozef Hrozienčík (red.), Československo and Juhoslávia. Z dejín československo-juhoslovanských vztahov, 269-284. Bratislava: 1968.

Stojkov, Todor. Opozicija u vreme šestojanuarske diktature 19291935. Beograd: Prosveta, 1969. 
Jana Škerlová

\section{ČEHOSLOVAČKO-JUGOSLOVENSKI ODNOSI U PRVOJ GODINI DIKTATURE KRALJA ALEKSANDRA}

\section{Rezime}

Posle duže političke krize u Kraljevini SHS, kralj Aleksandar I Karađorđević se 6. januara 1929. odlučio da uvede ličnu diktaturu. Čehoslovačka ga je podržala kao bliskog saveznika u nadi da će ova mera dovesti do stabilizacije unutrašnje situacije. Edvard Beneš je verovao kralju i drugim jugoslovenskim zvaničnicima, koji su ga uveravali da novi režim predstavlja privremeno rešenje koje će, kada se situacija za nekoliko meseci smiri, rezultirati donošenjem novog ustava. Tako je čehoslovački ministar spoljnih poslova, jedan od arhitekata Male Antante (saveza Čehoslovačke, Kraljevine SHS i Rumunije), težeći ka stabilizaciji podržao Kraljevinu SHS (od oktobra 1929. Kraljevinu Jugoslaviju) u međunarodnoj areni.

Ubrzo posle uvođenja diktature, od ostataka ukinutih političkih partija razvila se opozicija, a neki od njenih članova su nastojali da za borbu protiv režima potraže oslonac u inostranstvu, pa i u Čehoslovačkoj. Očekivali su da će im ta parlamentarna demokratija ponuditi pomoć ili barem neku vrstu moralne podrške (na primer kroz štampu) protiv diktature, ali to se nije dogodilo. Čehoslovački zvaničnici nisu želeli da rizikuju pogoršanje odnosa sa Beogradom i odbijali su svaki kontakt sa jugoslovenskom opozicijom, kao i kritiku jugoslovenskog režima. Slično se ponašala i čehoslovačka štampa, koja je predstavljala uvođenje diktature kao iznuđen korak u dramatičnim okolnostima i često isticala privremeni karakter ovih mera, u skladu sa stavovima čehoslovačke spoljne politike.

Oprezan stav Čehoslovačke i ministra Beneša predstavljao je značajnu podršku jugoslovenskoj diktaturi u nastojanjima da se konsoliduje i uspostavi kako na domaćoj sceni, tako i u međunarodnim odnosima.

KLJUČNE REČI: Čehoslovačka, Kraljevina Srba, Hrvata i Slovenaca, kraljevska diktatura, politički odnosi, diplomatija, Mala Antanta 


\section{VERHÄLTNISSE ZWISCHEN TSCHECHOSLOWAKEI UND SHS-KÖNIGREICH ANFANGS KÖNIGSDITATUR VON ALEKSANDAR KARAĐORĐEVIĆ}

\section{Zusammenfassung}

Nach einer langwierigen politischen Krise entschied sich König Alexandr Karađorđević am 6. Januar 1929 zur Ausrufung einer Diktatur im SHSKönigreich. Als enger Verbündeter unterstützte die Tschechoslowakei diese Maßnahme in der Hoffnung, dies würde zu einer Stabilisierung der Lage auf dem innenpolitischen Feld führen. Beneš glaubte den jugoslawischen Repräsentanten mit dem König an der Spitze, die ihm gegenüber immer wieder versicherten, dass das neue Regime eine lediglich vorübergehende Lösung mit Notstandscharakter darstelle, die nach einigen wenigen Monaten, bis sich die Lage beruhigt, in der Oktroyierung einer neuen Verfassung münden würde. Gleichzeitig wurde das SHS-Königreich (ab Oktober 1929 Jugoslawien) vom tschechoslowakischen Auslandsminister, der außerdem der Architekt der Kleinen Entente, eines Bündnisses der Tschechoslowakei, des SHS-Königreichs und Rumäniens, auf dessen Stabilität er besonderen Wert legte, auch auf dem internationalen Feld unterstützt.

Im SHS-Königreich begann sich bald nach der Ausrufung der Diktatur auf der Grundlage der ehemaligen politischen Parteien die Opposition zu formieren. Einige ihrer Angehöriger versuchten Hilfe im Kampf gegen das Regime auch im Ausland zu suchen, die Tschechoslowakei mit eingeschlossen. Von der dortigen parlamentarischen Demokratie erwarteten sie Hilfe oder zumindest eine Art moralische Unterstützung (ausgedrückt beispielsweise in der Presse) gegen die Diktatur, doch diese blieb leider aus. Die tschechoslowakischen offiziellen Vertreter wollten auf keinen Fall eine Verschlechterung der Beziehungen mit der Belgrader Regierung riskieren, und lehnten daher jeglichen Kontakt zur jugoslawischen Opposition und eine eventuelle Kritik am offiziellen jugoslawischen Regime ab. Ähnlich verhielt sich zumeist auch die tschechoslowakische Presse, die die Ausrufung der Diktatur am häufigsten als einen Schritt präsentierte, der durch ungünstige Umstände notwendig wurde, und häufig auch im Einklang mit der offiziellen tschechoslowakischen Auslandspolitik den außergewöhnlichen Charakter und die vorübergehende Geltung dieser Maßnahme betonte.

Die vorsichtige Haltung der Tschechoslowakei mit Minister Beneš an der Spitze half damit im Jahr 1929 in einem beträchtlichen Maße der jugoslawischen Diktatur sich in aller Ruhe zu festigen und zu etablieren, und das sowohl an der heimischen Szene, als auch auf dem internationalen Feld.

SCHLÜSSELWÖRTER: Tschechoslowakei, SHS-Königreich, Königsdiktatur, politische Verhältnisse, Diplomatie, kleine Entante 